\title{
UNIVARIATE METHOD OF MEASURING \\ NATURAL RATE OF INTEREST: ALBANIA
}

\author{
Altin Zefi ${ }^{1}$ \\ DOI: https://doi.org/10.31410/ERAZ.2019.159
}

\begin{abstract}
We use univariate methods to measure the natural rate of interest for Albania. Natural rate of interest is an important tool in monetary policy. It has been described as the rate that provides price stability and full employment. The natural rate of interest is widely used as an indicator for the monetary policy. A policy interest rate below the natural rate of interest is seen as expansionary, while a policy interest rate by a Central bank, is seen as contractionary for the monetary policy. We find that Albania's natural rate of interest is below zero while the real interest rate is also below zero but close to the natural rate of interest. We conclude that Albania's central Bank monetary policy is not as accommodative and expansionary as it's indicated in the central bank's public announcements.
\end{abstract}

Keywords: Monetary policy, natural rate of interest, negative interest rate, real interest rate.

\section{INTRODUCTION}

$\mathrm{N}$ atural rate of interest is an important tool in monetary policy. It has been described as the rate that provides price stability and full employment. Wicksell described it as such:

There is a certain rate of interest on loans which is neutral in respect to commodity prices, and tends neither to raise nor to lower them. This is necessarily the same as the rate of interest which would be determined by supply and demand if no use were made of money and all lending were effected in the form of real capital goods (Knut Wicksell- Interest and Prices, 1898 p .102)

European Economies have struggled with low economic indicators for the last 10 years. In order to jostle their numbers and economy back to growth they have experimented with unconventional tools like negative interest rate. In a state with negative interest rates banks and institutions pay the central banks a percentage in order to safeguard their money, instead of getting payments back on their deposits. These costs are passed down to the clients, who instead of being paid for depositing their money at the bank, are charged. This is supposed to discourage savings and bank deposits and instead encourage spending and through lower interest rate investments.

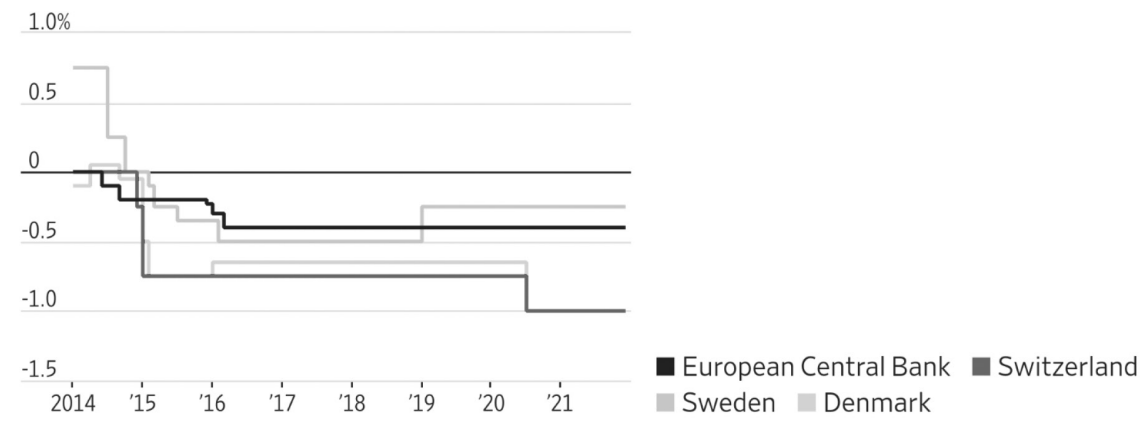

Figure 1: Central Bank rates. Source: European Central banks and wsj.com 
According to Blackstone (Blackstone, 2019) banks in the European economies struggle with slim profit margins due to low income on interest which in turn lower their ability to finance development. This has caused these banks to lag behind American counterparts.

Blackstone sees the negative effects of negative interest rates in many fronts. Firstly, the northern countries in Europe have a healthier development and don't need negative interest rates. Secondly, the countries that do need to have negative interest rates to boost their struggling economies aren't benefiting from it. Thirdly, negative or low interest rate help profitless companies stay afloat and as a result steering away recourses from more efficient and viable companies. Fourthly, allowing inefficient companies to stay in business produces an economy that is not as productive and competitive as in other countries where inefficient ideas are pushed off the market. Fifthly and lastly, and probably the most important negative interest rates for prolongated periods of time reduce the ability of Central banks to respond to unexpected economic downturns. In the scenario of crises Central banks don't have at their disposal this important conventional tool of lowering interest rates.

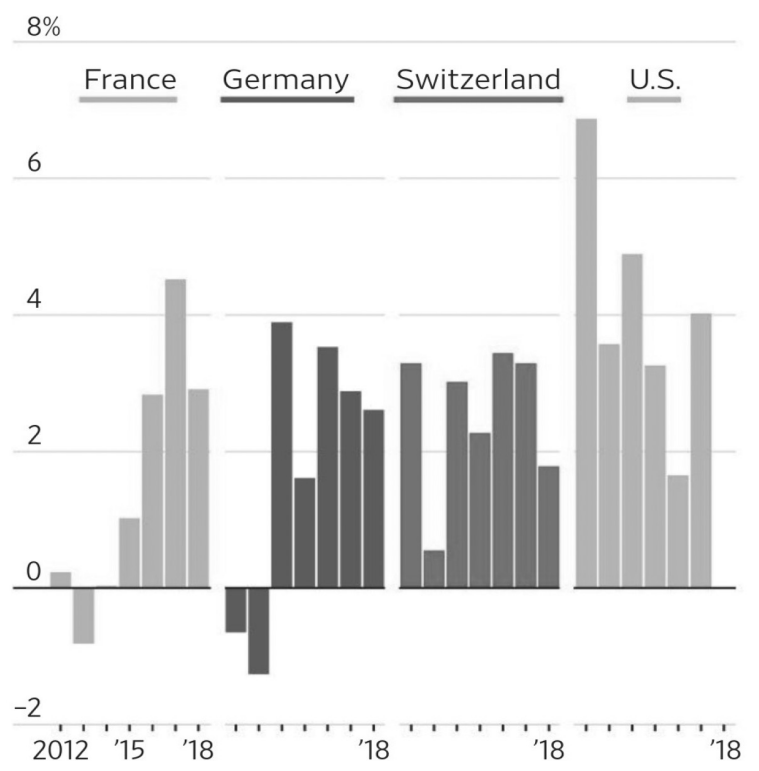

Figure 2. Annual changes in Capital investment.

Source: OECD and wsj.com. Note: 2018 data for U.S not available.

Despite negative interest rates capital investments have not soured, on the opposite data on capital investment have been sluggish. France had a growth to above 4\% in 2017 compared with right under 3\% in 2016 but in 2018 France Germany and Sweetland had a sharp decline to 2\% or less.

Albania has followed its world and European counterparts in lowering its base policy interest rate, the repo rate.

Although low interest rate, by the Albania's central Bank, have lowered the borrowing costs for consumers and businesses it is difficult to extract exactly has contributed to a small upturn in the economic activity.

Despite the accommodative monetary policy through low repo rates Albania has lagged behind almost all regional countries. 
Alternative Bank CEO, Martin Rohner says that negative interest is a new normal. Banks and large institutions, like hedge funds and pension funds, are increasingly understanding that this is a fact of life.

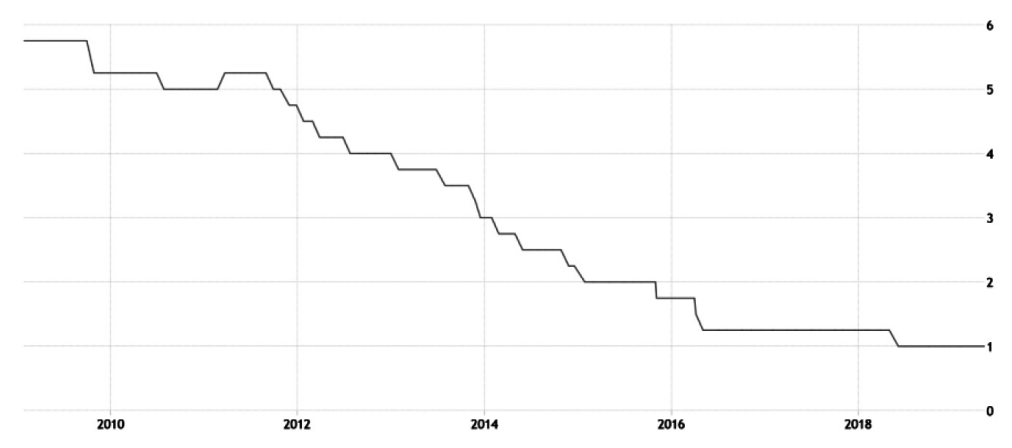

Figure 3: Albania's REPO rate.

Source: Bank of Albania

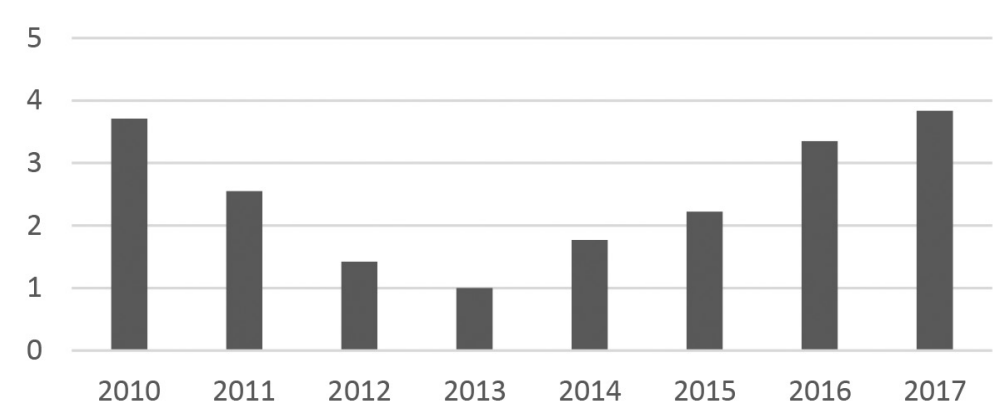

Figure 4. Albania's GDP change from previous year.

Source: Bank of Albania

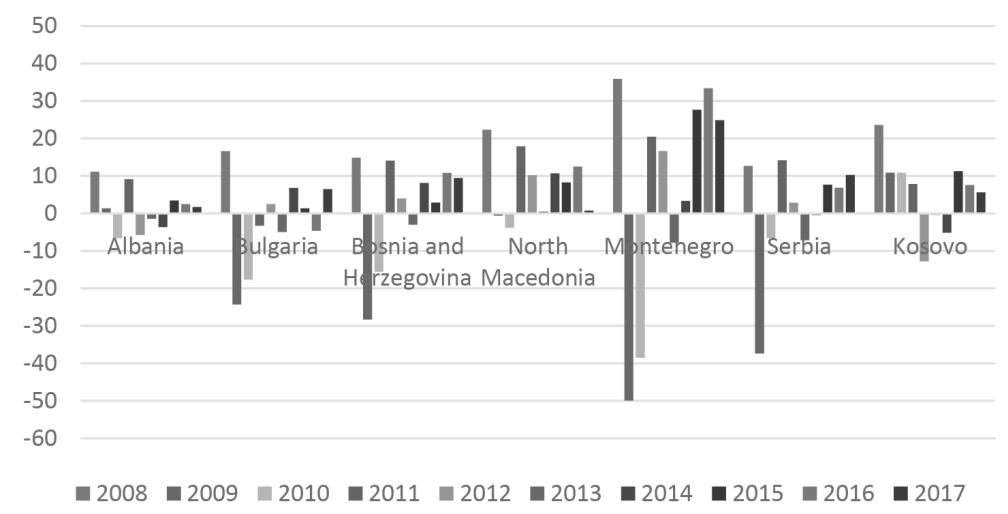

Figure 5. Gross capital formation across several economies.

\section{Source: World Bank}

Europe's negative interest rate has had a positive effect in Europe and a negative one in Albania. Low interest rate has lowered exchange rate which in turn has made exports from Europe cheaper and imports more expensive, thus attracting other countries to buy from them.

Albania struggles with a strong ALL and Central bank policy makers have not been able to tackle the problem.

Despite unprecedented low interest rate data suggests that lowering interest rate has not been adequate in jump starting the economy. 
We come to the question of this study: What is the natural interest rate, the interest that keeps full employment (or near natural rate of unemployment) potential growth of the economy and low inflation?

We shall try to answer this question.

\section{LITERATURE RESEARCH}

According to Lubik \& Mathes (Lubik \&Mathes, 2015) the natural interest rate is a key concept in monetary economics because it allows policy makers to assess if monetary policy is contracting economic activity or is it helping to accelerate it. Natural interest rate help interpret and analyze the connection of monetary policy to economic activity.

Natural interest rate usage dates back to Knut Wicksell who in the very far year of 1898 defined natural interest rate as the interest rate that produces a stable inflation.

According to Lubik et.al (ibid) its modern use can be attributed to Colombia professor Michael Woodford. Woodford in 2003 (Wodford, 2003) connected the natural rate of interest to modern macroeconomic thought.

Woodford (2003) says that "an inflation-targeting central bank can steer the economy toward the natural rate and price stability by conducting policy through the application of a Taylor rule, which links the policy rate to measures of economic activity and prices.".

For this reason, Central banks will have a high interest in measuring the natural interest rate and using it to steer monetary policy towards stable prices and full potential economies.

The figure below shows the process of determination of natural interest rate. IS curve is sloping downwards as the real interest rate affects negatively investments and savings. Potential GDP is, in short term, fixed.

The equilibrium real interest rate that supports potential GDP is the natural interest rate.

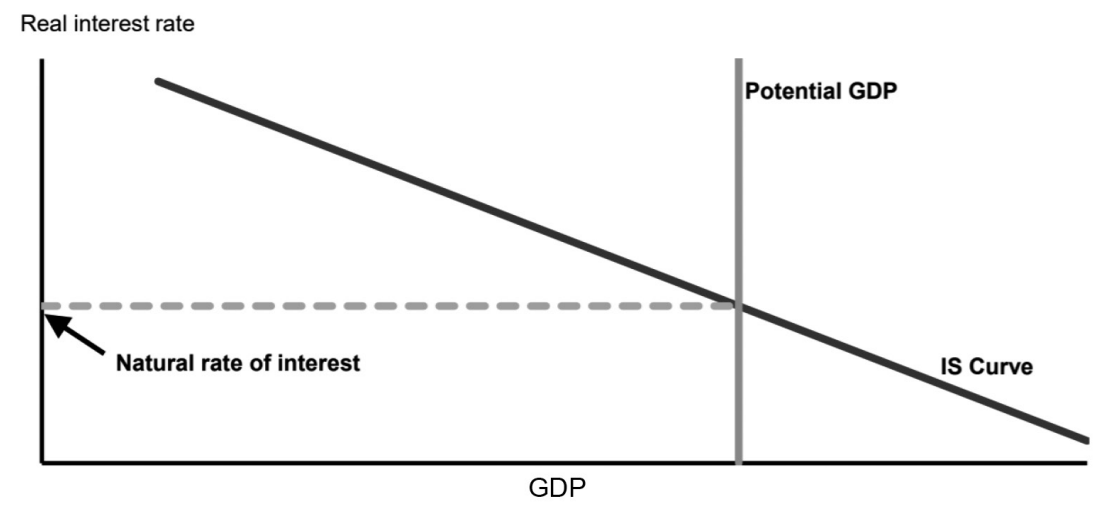

Figure 6. Determination of Natural Interest rate.

Source: Laubach\&Williams (2015)

Mosler and Forstater (2004) point to the fact that the concept of "natural" rates has been used for other economic indicators like the natural rate of unemployment and economic growth. 
Marshal didn't like the word "natural" as it implied a "law of nature" (Eatwell, 1987) with the word "normal". According to Mosler Et.al (2004) "natural" refers to conditions of values that hold under general conditions, rather than specific.

Same authors continue to argue that the natural interest rate trends towards zero in the conditions of a budget deficit and floating exchange rate.

Mosler and Forstater say: "In a state money system with flexible exchange rates running a budget deficit-in other words, under the 'normal' conditions or operations of the specified institutional context - without government intervention either to pay interest on reserves to offer securities to drain excess reserves to actively support a non-zero, positive interest rate, the natural or normal rate of interest of such a system is zero."

Evidence may support this conclusion. The dawn of the great financial crises and large government deficits have substantially reduced the natural rate of interest. These are the conclusions of then FED chairwoman Janet Yellen in her 2015 analyses.

Laubach and Williams made popular the idea that in the short run natural interest rate is important component of monetary policy as it relates the policy interest rate to that of the natural rate. It helps stabilizing and recovery during cycles of the economy.

\section{MODEL OF CALCULATING THE NATURAL RATE OF INTEREST}

\subsection{Univariate Methods of calculating natural rate of interest.}

Although such univariate time series methods could be unreliable during periods when inflation and economic activity are unstable, they can work well at estimating the natural rate of interest when inflation and economic activity are relatively stable. Univariate methods are likely to accurately measure the natural interest rates and when these rates have deviated from the natural rate (Laubach et al., 2015).

\subsection{HP filter}

HP filter is one the most commonly use filter to decompose trend growth from cycles.

The Hodrick Prescott method is widely used to estimate trend indicator and cycle movements. HP filter decomposes times series Yt in two components: trend component, which can be interpreted as the trend natural interest rate, and cyclical components, which is the deviation of real interest rate from natural interest rate trend.

$$
r_{t}=r_{t}^{*}+G_{t}
$$

This method assumes that the cyclical components fluctuate around the trend components with time diminishing amplitudes. Therefore, the average of the deviations of $r_{t}$ from $r^{*}$ is assumed to be near zero over a long period of time. HP filter minimizes variances according to a given weight $\lambda$. For yearly data, such as our case, a smoothing parameter $\lambda$ of 100 is used. The higher the $\lambda$ the smoother the trend will appear. 
Kota (2007) summarizes the drawbacks of univariate methods such as HP filter. As mentioned above univariate methods give good results during times of stable economy but are not very reliable in developing countries with highly unstable economies. Another disadvantage of the univariate methods is that the high-end sample biases. These methods use smoothing parameters to minimize deviations from trend. The minimization problem which derives the trend series, aims to penalize deviations from trend and smooth the trend series. At the end of sample, this penalization is missing; Therefore, the trend will react more to transitory shock at the end of the sample than at its middle, see Kota (2017).

\subsection{Multivariate methods of calculating Natural rate of interest}

According to Yellen (2015) there are four models for calculating natural rate of interest:

1. The dynamic stochastic general equilibrium (DSGE) model development by the staff of Federal Reserve Board and described by Kiley (2013),

2. DSGE model developed by the Federal Reserve of New York and described by Del Negro and other in (2013),

3. DSGE model developed by the staff of Federal Reserve Board based in Christiano, Motto and Rostagno, (2014),

4. Laubach-Williams model developed by Laubach and Williams (2015).

The shaded green are the variations between four models calculating the natural rate of interest. What is clear is that all four models report a decline in the natural rate of interest during the great recession and a small recovery.

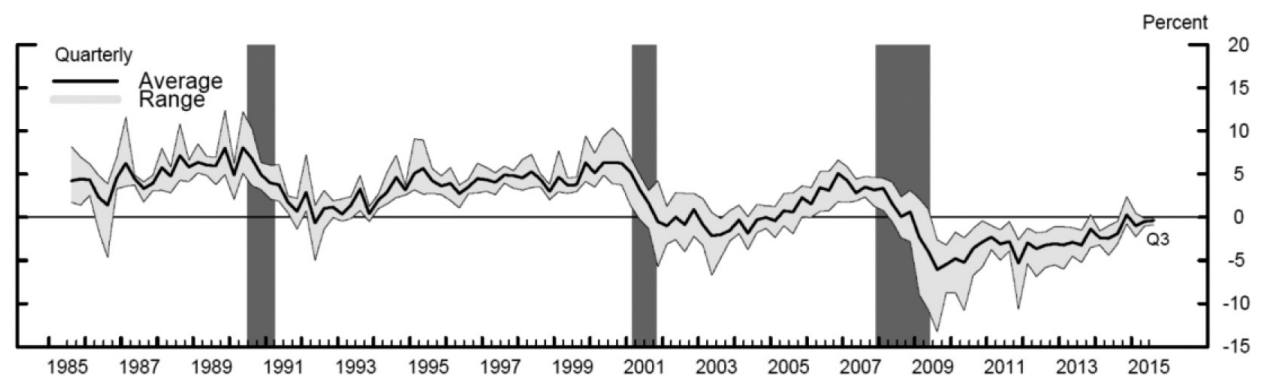

Figure 7. U.S. Natural rate of interest.

Source: Janet Yellen “The Economic Outlook and Monetary Policy” 2015.

\section{DATA ON UNIVARIATE MODEL FOR MEASURING NATURAL INTER- EST RATE}

Univariate method for measuring output gap and natural rate of interest are fairly reliable in periods of stability. Though it does not do well for prolonged periods of rising and decline in inflation (see discussion in Laubach \& William, 2001), these methods could in principle work quite well in times of stability.

Over such periods natural rate of interest mirrors quite well reflects the average of real interest rate.

Laubach and Williams (2015) suggest using real short-term interest rate long trend to measure natural rate of interest. The Central Bank of Albania uses REPO's (1 week repurchase agreement) as its main instrument of monetary policy to affect the short-term interest rate in order to affect other term interest rates. 


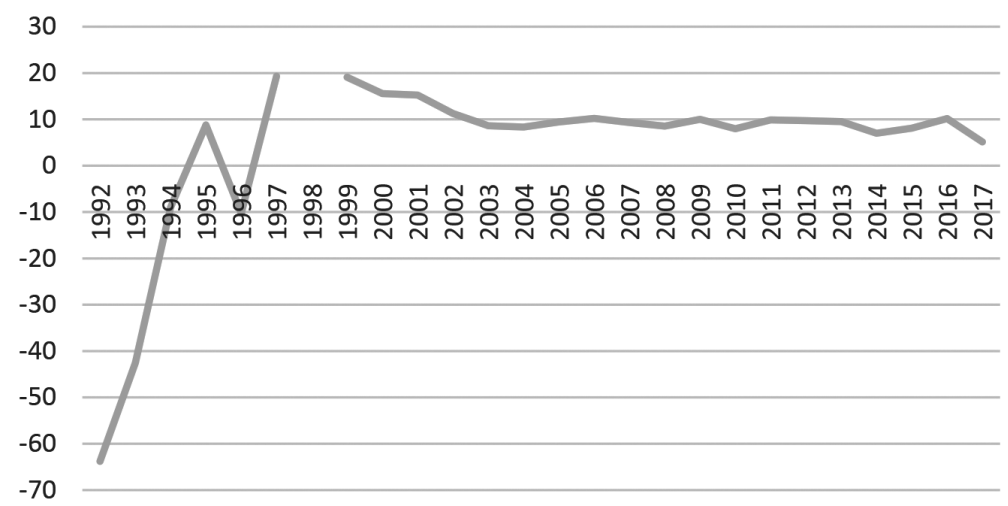

Figure 8: Albania's average real interest rate has been quite stable since 2001.

Source: Bank of Albania

Albania's shorter-term nominal REPO rate is shown in the following figure:

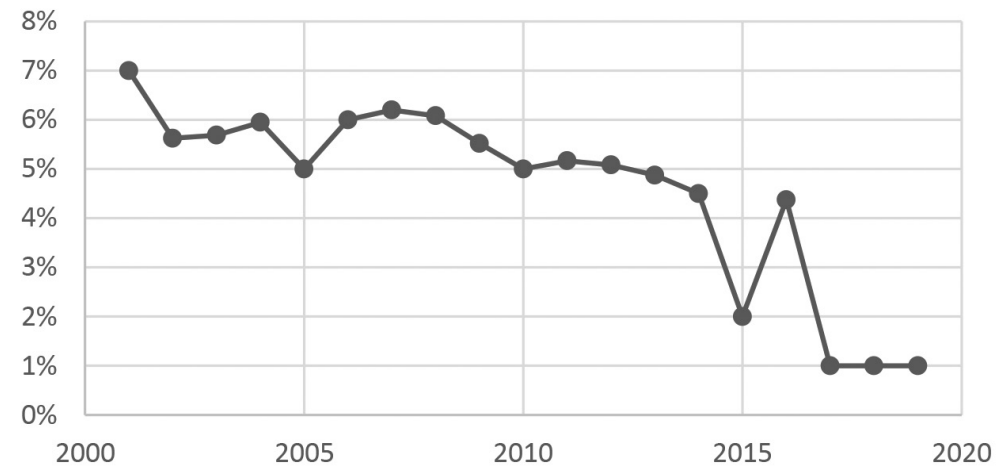

Figure 9. Nominal Repo Rate for Albania.

Source: Bank of Albania, Authors calculations

We have taken the average REPO rate of a year. Real nominal interest rate is calculated in the Phisher model through yearly CPI and we arrive at the real short-term REPO rate. Laubach\&Williams (2015) use the PCE index to arrive at the short-term real interest rate. CPI (Consumer Price Index) reports have reported higher inflation that PCE. Because we lack the PCE data for Albania we have substituted PCE with CPI and will be mindful of the tendency of CPI to report higher inflation.

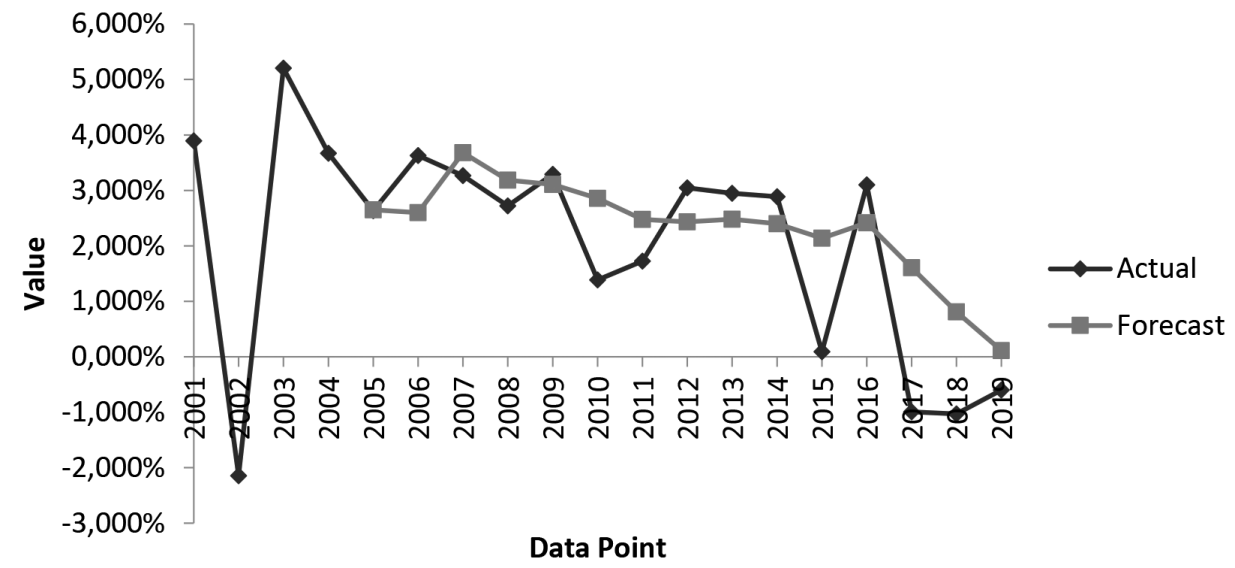

Figure 10. Univariate method - 5 year moving average.

Source: Bank of Albania and author's calculations 
ERAZ 2019

Conference Proceedings

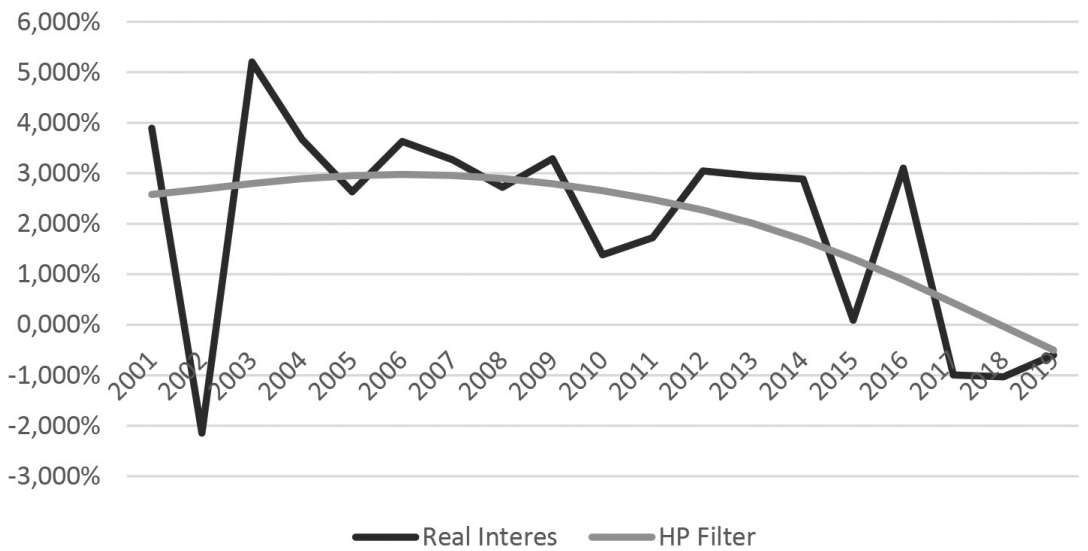

Figure 11. Natural rate of interest through HP filter.

Source: Author's calculations

As expected, the residue component is high during periods of high volatility in Albania. Deviations from trend get smaller as the country moves into periods of macroeconomic and financial stability.

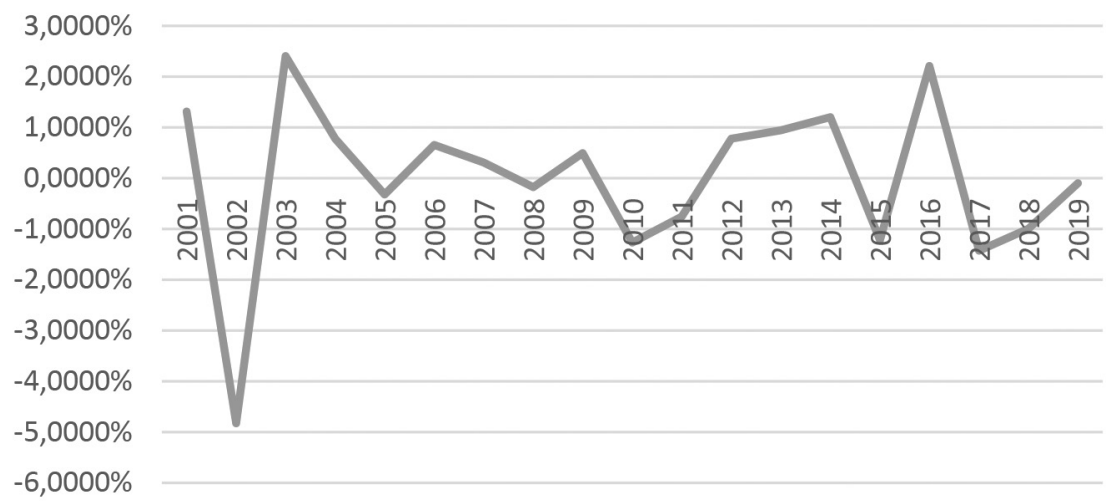

Figure 12. Cyclical component natural interest rate - Albania. Source: Author's calculations

We compare the real interest rate for Albania between 2001 and 2019 with 5 year moving average method and HP filter method.

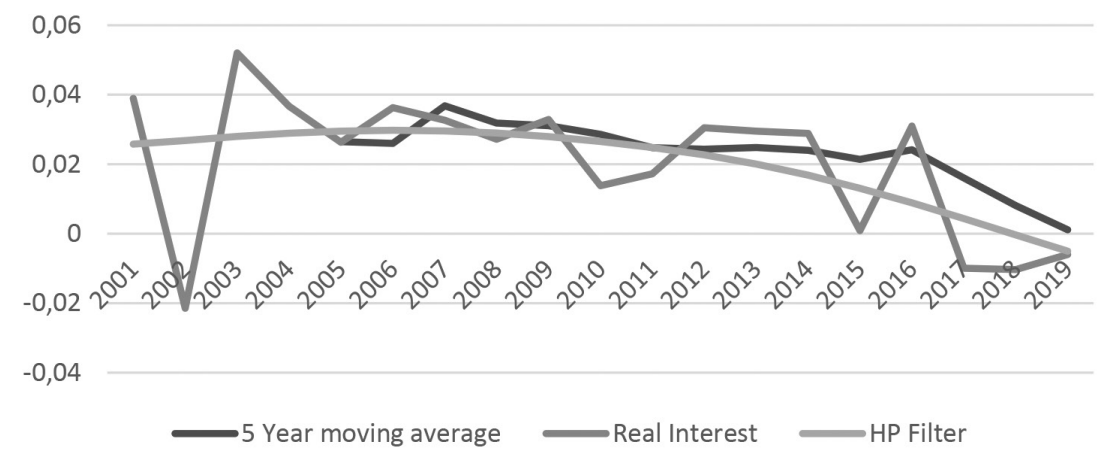

Figure 13. Real interest rate.

Source: Bank of Albania and author's calculations 


\section{DATA RESULTS}

Both methods show a steady decline in the natural rate of interest ensuing the Great Financial crises of 2008. The results show a two-sided estimate for the natural rate of interest for Albania. We have considered 18 year, between 2001 and 2019. 5 year moving average shows an increase in 2016 of the natural rates of interest but then follows the same trend result as the HP filter with sharp decline. HP filter calculates the natural of interest at below zero in 2019 while the 5 -year moving average calculates it at right above zero.

The trend is clear in both univariate methods of calculating the natural rate of interest. This represents a historically low level of the natural rate of interest. Same results are seen in EU and US calculations as in Laubach \& Williams (2015).

The decline in the natural interest rate is accompanied with decline in potential output.
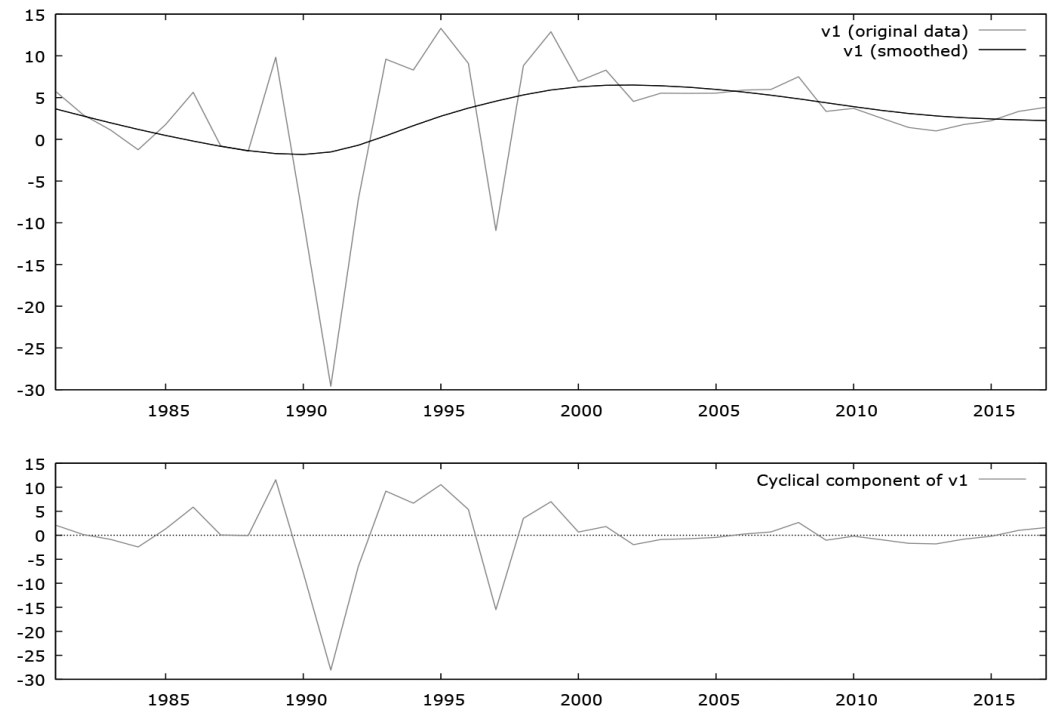

Figure 14. Albania output actual and potential $1981-2017$.

Source: Bank of Albania and the author's calculations

The Central bank of Albania has followed an accommodative monetary policy with key nominal interest rates at $1 \%$. Inflation has also stayed below the target inflation.

We conclude that monetary policy has not been as accommodative as policy makers think. The natural rate of interest is in the negative territory and the Central bank should have followed a more aggressive accommodative monetary policy to respond to the decline in potential output and low inflation.

More studies should be performed to see results from multivariate models of measuring natural rate of interest. These results should be compared with the univariate, as measured here, and plugged into models of implications for monetary policy.

What are the implications for the design of monetary policy strategies? In the context of simple policy rule of the Taylor model, strategies of monetary policy do not rely as much on the natural rate of interest. One possible way to substitute is the respond in a more robust way to inflation gap with a higher coefficient in the Taylor rule models. 


\section{REFERENCES}

[1] Brian Blackstone, (2019) Negative Rates, Designed as a Short-Term Jolt, Have Become an Addiction, wsj.com

[2] Knut Wicksell, (1936) Interest and Prices: A Study of the Causes Regulating the Value of Money, 1898, English translation, London: Macmillan and Company, p. 102.

[3] Thomas A. Lubik and Christian Matthes (2015): Calculating the Natural Rate of Interest: A Comparison of Two Alternative Approaches

[4] Michael Woodford, (2003), Interest and Prices: Foundations of a Theory of Monetary Policy, Princeton, N.J.: Princeton University Press.

[5] Warren Mosler and Mathew Forstater, (2004) The Natural Rate of Interest is Zero 2004 Working Paper No. 37

[6] Thomas Laubach, John Williams, (2015) Natural-interest-rate-redux, Federal Reserve Bank of San Francisco

[7] Thomas Laubach and John Williams, (2001) Measuring the natural rate of interest, Board of Governors of the Federal Reserve System.

[8] Vasilika Kota, (2007) Alternative methods of estimating potential output in Albania

[9] Vuslas Us, (2018) Measuring the Natural Interest Rate for the Turkish Economy

[10] Janet Yellen, (2015) The economic outlook and the monetary policy, Economic Club of Washington

[11] Moritz Schularick, Alan M. Taylor, (2010) Credit Booms Gone Bust: Monetary Policy, Leverage Cycles and Financial Crises, 1870-2008*

[12] Alejandro Justiniano and Giorgio E. Primiceri, (2010) Measuring the equilibrium real interest rate

[13] Karel Havik, Kieran Mc Morrow, Fabrice Orlandi, Christophe Planas, Rafal Raciborski, Werner Röger, Alessandro Rossi, Anna Thum-Thysen, Valerie Vandermeulen, (2014) The Production Function Methodology for Calculating Potential Growth Rates \& Output Gaps

[14] Genti Sejko, Governor or Central Bank of Albania, (2019) Monitor.al: E ardhmja dhe sfidat e ekonomisë e sistemit bankar 